\section{Voorwaardelijke PIJ voor ernstig verminderd toerekeningsvatbare minderjarige verdachte}

Rechtbank Oost-Brabant 13 maart 2019, ECLI:NL: RBOBR:2019:1379 (datum publicatie: 13 maart 2019)

De rechtbank acht poging tot doodslag wettig en overtuigend bewezen en legt aan een in 2001 geboren verdachte negentig dagen jeugddetentie op en een voorwaardelijke PIJ-maatregel met onder meer de voorwaarde van een klinische behandeling. De verdachte heeft op zeventienjarige leeftijd iemand met een mes neergestoken. Vanwege de ziekelijke stoornis en gebrekkige ontwikkeling van de geestesvermogens waar verdachte an lijdt, rekent de rechtbank hem de feiten - op advies van de deskundigen - in ernstig verminderde mate toe. Mede op advies van de RvdK acht de rechtbank oplegging van een voorwaardelijke PIJ voldoende. Daarbij neemt de rechtbank in aanmerking dat verdachte desgevraagd heeft aangegeven bereid te zijn zich te blijven conformeren aan de behandeling binnen GGZ 'De Catamaran', ook als dit in de vorm van bijzondere voorwaarden bij een voorwaardelijke PIJ-maatregel an hem wordt opgelegd in plaats van als een onvoorwaardelijke PIJ-maatregel.

\title{
Jeugdige vreemdeling
}

\section{Nieuws}

\section{Kinderpardon nog niet in lijn met \\ kinderrechten van alle gewortelde kinderen}

Op 11 februari 2019 heeft de Immigratie- en Naturalisatiedienst (IND) de criteria voor de Afsluitingsregeling van het kinderpardon bekendgemaakt. Met deze regeling wordt het Kinderpardon beëindigd. Kinderen konden nog een aanvraag indienen voor de Afsluitingsregeling tot en met maandag 25 februari 2019. Veel gezinnen die voorafgaand aan 29 januari 2019 al een aanvraag hadden ingediend op grond van de Definitieve regeling, hoefden dit niet opnieuw te doen. Defence for Children is opgelucht dat kinderen die langer dan vijf jaar in onzekerheid leven, nog een beroep kunnen doen op de regeling. Tegelijk is Defence for Children bezorgd over de kinderen die niet aan de nieuwe criteria lijken te voldoen. $\mathrm{Zij}$ maakt zich zorgen over kinderen die wel in beeld zijn bij de gemeente, maar niet meer in de opvang van het Rijk verblijven. Ook vindt zij het niet in lijn met de rechten van het kind dat kinderen gestraft worden wanneer een ouder in het verleden is veroordeeld via het strafrecht. Daarnaast vallen ook kinderen buiten de regeling waarvan de ouders niet op tijd of geen asiel hebben angevraagd in Nederland.

(Defence for Children)

\section{Literatuur}

\section{De zitting in de zaak Howick en Lili}

De vrij onverwachte verstrekking van een verblijfsvergunning aan Howick en Lili door de staatssecretaris, twee weken nadat de Afdeling bestuursrechtspraak van de Raad van State het groene licht had gegeven voor een eventuele uitzetting van de kinderen, leidde tot allerlei reacties. Blijdschap bij de kinderen en tegelij- kertijd verwondering bij velen over de precieze beweegredenen van de staatssecretaris om gebruik te maken van zijn discretionaire bevoegdheid. Dat laat echter onverlet dat de behandeling ter zitting door de Vreemdelingenkamer van de ABRvS niet getuigde van rechterlijke onpartijdigheid.

(C. Grütters, N7B 2019/254)

\section{Jurisprudentie}

Behoorde het kind feitelijk gezien tot het gezin van haar grootouders?

Hoge Raad 15 februari 2019, ECLI:NL: HR:2019:227 (datum publicatie: 15 februari 2019)

Verzoek tot naturalisatie. Aan de orde in deze cassatieprocedure is de vraag of - de inmiddels meerderjarige - verzoekster op grond van artikel 11 lid 1 Rijkswet op het Nederlanderschap (RWN (oud)) heeft gedeeld in het naturalisatiebesluit van haar biologische moeder.
In het kader daarvan moet worden vastgesteld of verzoekster verblijf voor onbepaalde tijd in Nederland was toegestaan op grond van artikel 10 lid 2 Vreemdelingenwet (oud) jo. artikel 47 Vreemdelingenbesluit (oud). Daarvoor geldt als voorwaarde dat verzoekster op het moment dat haar moeder werd genaturaliseerd (13 maart 1996) verblijf voor onbepaalde tijd in Nederland was toegestaan. Op dat moment woonde verzoekster in Nederland bij haar grootouders en was zij als 
hun kind ingeschreven. Later bleek dat verzoekster niet het kind van haar grootouders was, maar hun kleinkind. De vraag is of verzoekster bij die stand van zaken een verblijfsrecht kon ontlenen aan dat van haar grootouders. In de beschikking van 21 april 2017 heeft de Hoge Raad geoordeeld dat moet worden beoordeeld of verzoekster feitelijk deel uitmaakte van het gezin van haar grootouders. In de procedure na cassatie en terugwijzing heeft de Rechtbank Den Haag bij beschikking van 8 maart 2018 geoordeeld dat dit niet het geval was, omdat verzoekster weliswaar in één huis woonde met haar grootouders, maar in dat huis ook samenwoonde met haar beide ouders die op dat moment bovendien waren gehuwd. Tegen dat oordeel richten zich de cassatieklachten. De in het middel aangevoerde klachten kunnen volgens de Hoge Raad niet tot cassatie leiden.

Procedurele aspecten en IPR

Jurisprudentie

Geen ongeoorloofde overbrenging in de zin van Kinderontvoeringsverdrag

Rechtbank Den Haag 4 februari 2019, ECLI:NL: RBDHA:2019:988 (datum publicatie: 4 maart 2019)

Verzoek vader tot teruggeleiding kinderen naar Spanje. De rechtbank oordeelt dat angenomen moet worden dat de vader en de moeder, en daarmee de kinderen, in elk geval vanaf eind augustus 2016 steeds twee (wisselende) gewone verblijfplaatsen hebben gehad, te weten Nederland en Spanje. Het feit dat de kinderen in Spanje zijn geboren en daar de eerste zeven weken van hun leven hebben doorgebracht, is tegen de achtergrond van de steeds wisselende verblijven van de ouders onvoldoende om vast te stellen dat hun gewone verblijfplaats in Spanje is. Daarbij komt dat niet is gebleken dat de ouders op enig moment een bewuste en definitieve keuze hebben gemaakt de kinderen in Spanje (dan wel in Nederland) groot te brengen. $\mathrm{Nu}$ de ouders afwisselend in twee landen verbleven, kan geen sprake zijn van een (on)geoorloofde overbrenging of vasthouding in de zin van het Verdrag. Het Verdrag voorziet niet in de situatie dat niet één duidelijke gewone verblijfplaats kan worden aangewezen. De rechtbank komt daarom niet toe aan de bespreking van de andere aangevoerde stellingen en verweren die zijn gegrond op de toepasselijkheid van het Verdrag. Het verzoek van de vader wordt afgewezen.

\section{Beëindiging gezag vader die met minderjarige in India verblijft}

Rechtbank Noord-Holland 14 februari 2019, ECLI:NL: RBNHO:2019:1686 (datum publicatie: 4 maart 2019)

De RvdK verzoekt het gezag te beëindigen van een vader die zijn minderjarige dochter zonder toestemming van de moeder mee naar India heeft genomen. De rechtbank wijst het verzoek toe. Los van de vraag of er al dan niet sprake is van ontvoering, staat vast dat de minderjarige in een belangrijke levensfase, waarin zij bezig was zich te hechten, van de ene op de andere dag is weggehaald bij haar moeder die op dat moment de verzorgende ouder was en van Nederland naar India is overgebracht. De vader is de afgelopen twee jaar niet in staat geweest om contact mogelijk te maken tussen de moeder, de minderjarige en haar zus. Pas recent is er onder grote en voortdurende druk van de Indiase rechter voor het eerst in twee jaar contact geweest, maar dit contact is niet structureel, ondanks de 'orders' van de Supreme Court van India. Hoewel er bij de RvdK geen zorgen zijn over de welstand waarin de minderjarige opgroeit, zijn er wel grote zorgen over haar emotionele ontwikkeling. Deze zorgen worden door de rechtbank gedeeld. Behalve de vader weet niemand hoe het met de minderjarige gaat, wat haar is verteld en wat dit alles met haar doet. Het blijft onduidelijk of er voor de minderjarige hulpverlening in India is ingezet. De vader informeert de moeder niet over het welzijn en de ontwikkeling van de minderjarige en is niet in staat het gesprek met de moeder over de minderjarige aan te gaan. Dit alles leidt tot het oordeel dat de minderjarige zodanig opgroeit dat zij in haar ontwikkeling wordt bedreigd en dat deze situatie al dermate lang voortduurt dat de aanvaardbare termijn is overschreden. Daarmee is naar het oordeel van de rechtbank voldaan aan het gestelde in artikel 1:266, eerste lid onder a, BW.

\section{Geen doorbreking appel-verbod}

Gerechtshof 's-Hertogenbosch 7 maart 2019, ECLI:NL: GHSHE:2019:924 (datum publicatie: 8 maart 2019)

De minderjarige is op 6 februari 2017 uit huis geplaatst in een voorziening voor pleegzorg. De moeder heeft verzocht tot vervanging van de GI. Dit verzoek is door de rechtbank afgewezen, waartegen zij in hoger beroep gaat. Zij beroept zich ter zitting in hoger beroep op doorbreking van het appelverbod op grond van het belang van het kind. Het hof acht haar echter niet-ontvankelijk in haar verzoek, nu de grief tegen de doorbreking van het appelverbod voor het eerst is gedaan tijdens de mondelinge behandeling, hetgeen in dit geval te laat is. 